\title{
Health professionals' willingness to pay and associated factors for human papilloma virus vaccination to prevent cervical cancer at College of Medicine and Health Sciences University of Gondar, Northwest Ethiopia
}

\author{
Abebe Ayinalem Tarekegn ${ }^{1 *}$ and Ayenew Engida Yismaw ${ }^{2}$
}

\begin{abstract}
Objective: Preferences of health professionals' for human papilloma virus vaccines was measured by monetary value through willingness to pay (WTP) approach that could help policy makers set priorities among alternative cervical cancer prevention methods in poor countries. The objective of this study was to assess the female health professionals' willingness to accept and pay, and associated factors for human papilloma virus vaccination at College of Medicine and Health Sciences, University of Gondar, Northwest Ethiopia.

Results: The majority (85.97\%) of health professionals' were willing to pay for Human papilloma virus vaccine. On the average, the respondents were willing to pay 231.34 ETB (US\$8.50) per human papilloma virus vaccination service. Age, educational status, knowledge about cervical cancer and its risk factors and monthly income were identified as significant factors to WTP for human papilloma virus vaccination. Policy makers shall consider human papilloma virus vaccine to prevent cervical cancer maintain health of women's and do more on rising awareness of individuals about cervical cancer and its risk factors.
\end{abstract}

Keywords: Cervical cancer, Human papilloma virus, Willingness to pay, University of Gondar

\section{Introduction}

Cervical cancer is a chronic disease that arises due to the abnormal growth of cells from lower part of uterus which projects to the vagina [1]. Among the causes of cervical cancer, human papilloma virus which account for over $99 \%$ of all cases and around $73 \%$ is due to HPV16/18 human papilloma viruses [2]. Type of human papilloma virus (HPV), immune suppression, multi-sexual partner, HPV co-infection with other sexually transmitted agents human immunodeficiency virus, multiparity and family history are risk factors which increases persistence of

\footnotetext{
*Correspondence: aynu877@gmail.com

${ }^{1}$ Department of Health Service Management and Health Economics, Institute of Public Health and Department of Human Anatomy, University of Gondar, Gondar, Ethiopia

Full list of author information is available at the end of the article
}

human papilloma virus infection of cervical to develop cervical cancer [3-5].

Every year, about 500,000 cervical cancer cases are diagnosed [6] and Sub-Saharan African countries account $22 \%$ of all cases in the globe [7]. Cervical cancer causes 266,000 women to die each year in the world [3]. In Eastern Africa, cervical cancer is estimated to be 42.7 cases per 100,000 women and cervical cancer causes death of 35 per 100,000 women [3, 4, 8, 9]. The incidence and death rate of cervical cancer was 26.4 and 18.4 per 100,000 women's in Ethiopia, respectively [10].

Loss of $1.5 \%$ of the world's gross domestic product (GDP) associated with cancer due to mortality and incapacity without including direct medical cost of the treatment. In low-income countries burden of cancer was associated with sickness and death of mouth and throat 
cancer, cervix cancer, and breast cancer which were costing 1.3US\$ billion, 1.3US\$ billion and 1.1US\$ billion respectively, in 2008 [11].

Many countries in the world adopt human papilloma virus vaccine (HPV) as a strategy to overcome health and economic challenges which comes with cervical cancer [3].

The government of Ethiopia had launched cervical cancer screening program in different site with the help of donors since 2013 and has a plan to introduce HPV in the country so as to prevent the incidence and negative impact of cervical cancer. To introduce HPV vaccine to Ethiopia, there is a need to study on willingness to accept and pay for HPV vaccine. Therefore this study was aimed to assess the acceptance rate of female health professionals for HPV vaccine and its benefit interim of money through willingness to pay approach.

Besides, policy makers may know and look for optional strategies to tackle cervical cancer.

\section{Main text}

\section{Methods and material}

\section{Study design and setting}

Institutional based cross sectional study was conducted to investigate factors associated with willingness to accept and pay for HPV at the College of Medicine and Health Sciences, University of Gondar. The University of Gondar is a higher institution in Ethiopia located in northwest part of the country. The study was conducted from March 1st to April 30th, 2018.

\section{Study population and sampling}

All female health professionals who were working at CMHS were the study population.

The sample size of the study was calculated by using single population proportion formula for willingness to pay using the Epi Info ${ }^{\text {TM }} 7$ Stat Calc program with the assumption of $50 \%$ willingness to pay (p), 95\% confidence level, $5 \%$ margin of error, and $10 \%$ response rate. The final sample size of the study was 423 female health professionals.

The study participants were selected randomly by lottery method from the list of study population.

\section{Data collection procedures}

An interviewer administered questionnaire was used to collect the data. Double-bounded dichotomous choice variant of the Contingent Valuation method and hypothetical scenario about HPV which was used to estimate the benefit of the program by eliciting the WTP of female health professionals. This method was used to estimate the benefit of the program in terms of monetary unit. The study participants were asked the maximum amount they were willing to pay for the service they got per visit.

\section{Operational definitions}

Willingness to pay is the maximum price the study participant will definitely be willing to buy per unit of a service.

Contingent value method is an approach where the study participant was first asked whether they would be willing to pay 200 ETB per service to elicit the preference and then the question was repeated using a higher or lower bid value depending on the response to the first question until reaching to the final maximum amount the study participant will definitely buy.

\section{Data processing and analysis}

The data were entered into EpiData version3.1 software and was exported to STATA version14 software for analysis. Tobit model was used to estimate and identify determinants of willingness to pay. Tobit model is used to estimate outcome variables from censored data (skewed distribution of data). This model also predicts maximum amount of money that individuals were willing to pay for human papilloma virus vaccine. This model has an advantage over logistic discrete choice model in that it reveals the maximum amount of money the respondents were willing to pay.

$$
y= \begin{cases}1 & \text { i. MWTP }=\beta o+\beta^{\prime} \mathrm{Xi}+\mathrm{e}>0 \\ 0 & \text { if MWTP } \leq 0\end{cases}
$$

where, $\quad \mathrm{Y}=$ outcome $\quad$ variable; $\mathrm{MWTP}=$ maximum WTP; $\mathrm{Xi}=$ explanatory variables; $\beta \mathrm{o}=$ slope; $\beta^{\prime}=$ coefficient; $\mathrm{e}=$ error term; $1=$ success/yes; $0=$ failure/ no. $\mathrm{p}$-value $=0.05$ was used to determine statistical significance.

\section{Results}

Socio-demographic and economic, and health status and services related characteristics of the respondents A total of 392 study participants, with a response rate of $92.7 \%$, were included in the study. The mean age of the respondents was 28 years. Majority of respondents were Orthodox, Amhara, single, first degree holders and nurses (Table 1). Average monthly income of participants was $6177.47 \mathrm{ETB}$. Around $57.4 \%$ of respondents had high perceived quality of the HPV vaccine service and $56.63 \%$ of respondents said they had a good health status (Table 1).

\section{Health professionals' knowledge on cervical cancer and its risk factors}

In this study $97.96 \%$ of respondents had heard about human papilloma virus vaccine. Schools were the main means of information about HPV vaccine for $60.68 \%$ 
Table 1 Demographic, socioeconomic and health status and services related characteristics of study participants at CMHS, 2018

\begin{tabular}{|c|c|c|}
\hline Variable & Description & Frequency (\%) \\
\hline \multirow[t]{4}{*}{ Religion of the respondent } & Orthodox & $318(81.33 \%)$ \\
\hline & Muslim & $53(13.55 \%)$ \\
\hline & Protestant & $17(4.35 \%)$ \\
\hline & Others & $3(0.77 \%)$ \\
\hline \multirow[t]{4}{*}{ Ethnicity of the respondent } & Amhara & $347(88.52 \%)$ \\
\hline & Tigre & $24(6.12 \%)$ \\
\hline & Oromo & $10(2.55 \%)$ \\
\hline & Others & $11(2.81 \%)$ \\
\hline \multirow[t]{4}{*}{ Marital status of the respondent } & Single & $242(61.73 \%)$ \\
\hline & Married & $136(34.69 \%)$ \\
\hline & Divorced & $11(2.81 \%)$ \\
\hline & Widowed & $3(0.77 \%)$ \\
\hline \multirow[t]{6}{*}{ Background professional specialities of the respondent } & Nurse & $185(47.19 \%)$ \\
\hline & Midwifery & $79(20.15 \%)$ \\
\hline & Public health officer & $45(11.48 \%)$ \\
\hline & Pharmacy & $44(11.22 \%)$ \\
\hline & Medical laboratory & $23(5.87 \%)$ \\
\hline & Others & $16(4.08 \%)$ \\
\hline \multirow[t]{3}{*}{ Educational status of the respondent } & Diploma & $73(18.62 \%)$ \\
\hline & First degree & $277(70.66 \%)$ \\
\hline & Second degree & $42(10.71 \%)$ \\
\hline \multirow[t]{3}{*}{ Health status of participants $(n=392)$} & Poor & $34(8.67 \%)$ \\
\hline & Medium & $136(34.69 \%)$ \\
\hline & Good & $222(56.63 \%)$ \\
\hline \multirow[t]{5}{*}{ Perceived quality of the service $(n=392)$} & Very low & $12(3.06 \%)$ \\
\hline & Low & $60(15.31 \%)$ \\
\hline & Medium & $42(10.71 \%)$ \\
\hline & High & $225(57.40 \%)$ \\
\hline & Very high & $53(13.52 \%)$ \\
\hline
\end{tabular}

respondents. Among the respondents $68.62 \%$ had excellent knowledge about cervical cancer danger signs and its risk factors (Table 2).

\section{Willingness to pay (WTP) for HPV service}

Most of respondents (85.97\%) were willing to pay for human papilloma virus vaccination. Among participants $56.37 \%$ of them were willing to pay more than 200ETB and $31.63 \%$ were willing to pay more than $300 \mathrm{ETB}$. The mean $( \pm \mathrm{SD})$ amount of money health professionals willing to pay was $231.34 \mathrm{ETB} \pm 132$ per visit or 7.16 \$USD.

It's calculated as follows:
Currency exchange in March 2018 was $1 \$ \mathrm{USD}=27.2 \mathrm{ETB}$.

Factors associated with willingness to pay for HPV to prevent cervical cancer

The study showed that age, educational status, knowledge about cervical cancer and its risk factors and monthly income were factors statistically associated with willingness to pay for HPV vaccination in the multivariable analysis of Tobit model at a $\mathrm{p}$-value $\leq 0.05$ (Table 3).

$$
\begin{aligned}
\text { AMWTP } & =\sum_{n=1}^{392}(\text { MWTP1 }+ \text { MWTP2 }+\cdots \ldots \ldots . .+ \text { MWTP545 }) \div 392 \\
& =231.34 \text { ETB per HPV vaccination service }
\end{aligned}
$$


Table 2 Health professionals' knowledge about cervical cancer and its risk factors at CMHS 2018

\begin{tabular}{|c|c|c|}
\hline Variable & Description & Frequency $\%$ \\
\hline \multirow[t]{2}{*}{ Do you have heard about human papilloma virus vaccine? $(n=392)$} & Yes & $384(97.96 \%)$ \\
\hline & No & $8(2.04 \%)$ \\
\hline \multirow[t]{5}{*}{ What is your source of more information $(n=384)$} & School & $233(60.68 \%)$ \\
\hline & TV/Radio & $101(26.30 \%)$ \\
\hline & Training & $33(8.59 \%)$ \\
\hline & Internet & $14(3.65 \%)$ \\
\hline & Other & $3(0.78 \%)$ \\
\hline \multirow[t]{3}{*}{ Perceived seriousness of cervical cancer (392) } & Less serious & $52(13.27 \%)$ \\
\hline & Serious & $227(57.91 \%)$ \\
\hline & Highly serious & $113(28.83 \%)$ \\
\hline \multirow[t]{3}{*}{ Knowledge of respondents $(n=392)$} & Poor knowledge & $27(6.89 \%)$ \\
\hline & Moderate knowledge & $96(24.49 \%)$ \\
\hline & Excellent knowledge & $269(68.62 \%)$ \\
\hline
\end{tabular}

Table 3 Factors associated with WTP for human papilloma virus vaccination in CMHS, University of Gondar, 2018

\begin{tabular}{|c|c|c|c|c|c|c|}
\hline Parameter for MWTP & Category & Coefficient & Standard error & t-value & p-value & $95 \%$ confidence interval \\
\hline Age & $\mathrm{N}$ & -2.4 & 1.2 & -2.00 & 0.047 & $-4.8,-0.04$ \\
\hline Marital status (ref. married) & $\mathrm{S}$ & & & & & \\
\hline Single & & -6.8 & 12.1 & -0.57 & 0.572 & $-30.6,16.9$ \\
\hline Divorced & & -4.4 & 35.1 & -0.13 & 0.899 & $-73.4,64.5$ \\
\hline Widowed & & 19.7 & 56.1 & 0.35 & 0.726 & $-90.8,130.2$ \\
\hline Background profession (ref. public health officer) & S & & & & & \\
\hline Pharmacy & & 17.6 & 21.5 & 0.82 & 0.414 & $-24.8,60$ \\
\hline Nurse & & -12.8 & 17.3 & -0.74 & 0.461 & $-46.8,21.3$ \\
\hline Midwifery & & -7.9 & 19.5 & -0.40 & 0.686 & $-46.3,30.5$ \\
\hline Medical laboratory & & -2.4 & 29.3 & -0.08 & 0.935 & $-60.1,55.3$ \\
\hline Others & & -38.5 & 27.6 & -1.40 & 0.164 & $-92.8,15.8$ \\
\hline Educational status (ref. Diploma) & $\mathrm{S}$ & & & & & \\
\hline First degree & & -63 & 19 & -3.32 & 0.001 & $-100.4,-25.7$ \\
\hline Second degree & & -10.5 & 26.9 & -0.39 & 0.697 & $-63.4,42.4$ \\
\hline Knowledge (ref. poor knowledge) & $S$ & & & & & \\
\hline Moderate knowledge & & 56.8 & 26.1 & 2.18 & 0.030 & $5.6,108.1$ \\
\hline Excellent knowledge & & 69.7 & 24.3 & 2.87 & 0.004 & $22,117.5$ \\
\hline Health status (ref. poor & S & & & & & \\
\hline Medium & & -24.6 & 21.9 & -1.12 & 0.262 & $-67.6,18.4$ \\
\hline Good & & -18.6 & 20.6 & -0.90 & 0.367 & $-59,21.9$ \\
\hline Perceived seriousness cervical cancer (ref. less serious) & S & & & & & \\
\hline Serious & & -35 & 17.9 & -1.95 & 0.053 & $-70.4,0.4$ \\
\hline Highly serious & & -21.3 & 19.6 & -1.09 & 0.278 & $-59.8,17.3$ \\
\hline \multirow[t]{2}{*}{ Monthly income (Birr) } & N & & & & & \\
\hline & & 0.03 & 0.004 & 8.77 & $0.000^{* * *}$ & $0.03,0.04$ \\
\hline
\end{tabular}

Italic values indicate statistically significant associations

$S$ string variable, $N$ numeric value and $D$ Dummy variable

* Significant with $p$-value $\leq 0.05$

*** Significant with $p$-value $\leq 0.001$

As age increased by 1 year, respondents were willing to pay decreased by 2.5 Birr for human papilloma virus vaccination by holding other variables constant (Table 3 ).
First degree holders were willing to pay 63ETB less than those diploma holders for HPV vaccine by keeping other variables constant (Table 3). 
The respondents who had excellent knowledge about cervical cancer were willing to pay 69.7ETB more than those who had poor knowledge for human papilloma virus vaccine by keeping other variables constant (Table 3 ).

As monthly income of the respondents increased by $1 \mathrm{ETB}$, the willingness to pay increased by $0.04 \mathrm{ETB}$ for human papilloma virus vaccination by holding other conditions constant (Table 3).

\section{Discussion}

The finding of the present study showed that age, educational status, knowledge about cervical cancer and its risk factors and monthly income were significant determinants of willingness to pay for human papilloma virus vaccination.

This study revealed that $85.97 \%$ were willing to pay for HPV service. The result was line with studies done in Arba Minch town in 2011 on willingness to pay for insecticide treated bed net (86\%) [12]. On the other side, this study showed that willing to pay health professionals for HPV were higher than willing to pay for injectable contraceptive and foot wear for podoconiosis which were $(68 \%)$ and $(72.8 \%)$ respectively, in studies done in Tigray and northern Ethiopia $[13,14]$. This may be due to study population difference which may not have equal information about health. However, the result of the study was lower than willingness of respondents to pay for health service in Iran which was $88.8 \%$ [15]. The possible reason might be difference in study areas, cultural and demographic and study population differences.

The average amount of money, the respondents willing to pay for HPV, was 231.34ETB (US\$8.51) which was greater than the price used to elicit preference by 31ETB. The amount of money respondents were willing to pay for HPV was much higher than the amount of money respondents were willing to pay for injectable contraceptive per service and footwear for podoconiosis per year which were 11 Birr (US\$0.65) and 64 Birr (US\$ 3.28) [13, 14]. The possible explanation for this may be study population difference, the currency inflation and program differences. But the result of the study was lower than a study done on willingness to pay for HPV vaccine which was US\$ 11.68 in Nigeria [16] and US\$ 50.26 in Malaysia [17], and WTP for the clinical preventive services which was US\$93.72 in South-Nigeria [18]. This may be due to the difference in socioeconomic difference of the participants like per capita income, study population difference.

The age of respondents had negatively associated with willingness to pay. The negative association may be as age respondents' increase, they may have less family income due to large family than younger age groups might be the possible explanations. This result was inconsistent with studies done on WTP for Pap test in Nigeria [19], willingness to pay for health care services in Malaysia [20] and Iran [21] had a positive association with WTP. The possible difference might be different per capital income of those countries. This result contradicted with studies done on WTP for mortality risk reduction from the environment in USA [22] which reveals age does not have association with WTP for mortality risk reduction. One possible explanation for this difference may be all age groups equally risky by environmental risk factors in studies done USA.

This study also showed that educational status was identified as significant variable to WTP for HPV. Possibly this might be as educational status increases, individuals might have more information and aware about their health issues. This report was consistent with studies done Addis Ababa [23], Malaysia [20], Iran [21], Arba Minch [12] which revealed educational status had positive association with the preference and utilization of different health services.

The knowledge of health professionals' about cervical cancer and its risk factors had statistical association with willingness to pay. The possible explanation for this might be as individuals know more about cervical cancer and its risk factors, they become more willing to prevent cervical cancer. This finding was consistent with other studies conducted in Ethiopia [24], USA [25] which showed association of knowledge with the preference and utilization of different health services.

The monthly income of the respondents' had significant association WTP for human papilloma virus vaccination. This may be due to those having more income may had additional money to be allocated for promotion of their health in addition to basic needs. Studies conducted in Addis Ababa [23], Malaysia [20] Iran [15], Korea [26] and USA [27] for different health care services supported this evidence.

\section{Conclusion and recommendation}

This study indicated that majority of the health professionals were willing to pay for HPV Vaccination service. Age, educational status, knowledge about cervical cancer and its risk factors, and monthly income of the respondents were statistically associated with willingness to pay for HPV service.

Policy makers shall consider human papilloma virus vaccine to prevent cervical cancer maintain health of women's and do more on rising awareness of individuals about cervical cancer and its risk factors.

\section{Limitation of the study}

The method used in this study is partial economic evaluation approach which it did not account other cervical cancer prevention methods. The study only includes 
educated female health professional might be the limitation of this study. Another limitation of this study was respondents' bias that aims to reduce the cost of payment to the service and those have family history of cervical cancer need HPV vaccination might overestimate the cost.

\section{Abbreviations}

AMWTP: average maximum willingness to pay; CHMS: College of Medicine and Health Sciences; CV: Contingent Valuation; ETB: Ethiopian Birr; HPV: human papilloma virus vaccine; MWTP: maximum willingness to pay; UoGSRH: University of Gondar Specialized Referral Hospital; USA: United Nation of America; USD: United Nation Dollar; WTP: willingness to pay.

\section{Authors' contributions}

AAT conceived and design the idea, participated in the data collection process, analyze data and wrote the paper. AEY participated in data analysis and wrote the paper. Both authors read and approved the final manuscript.

\section{Author details}

${ }^{1}$ Department of Health Service Management and Health Economics, Institute of Public Health and Department of Human Anatomy, University of Gondar, Gondar, Ethiopia. ${ }^{2}$ School of Midwifery, College of Medicine and Health Sciences, University of Gondar, Gondar, Ethiopia.

\section{Acknowledgements}

We would like to forward our heartfelt gratitude to the Institute of Public Health, College of Medicine and Health Sciences, University of Gondar for providing the ethical clearance and supporting us in the process of this research. We would also like to extend our gratitude to data collectors and study participants for their active participation committing their time.

\section{Competing interests}

The authors declared no potential competing interest with respect to the research, authorship and publication of this article.

\section{Availability of data and materials}

Not applicable.

\section{Consent for publication}

Not applicable.

\section{Ethics approval and consent to participate}

Ethical approval was obtained from the Institutional Review Board (IRB) of the Institute of Public Health, College of Medicine and Health Sciences, University of Gondar. Permission letter from Gondar University Hospital was also secured before data collection. Names of patients were not included during data collection. The consent of participants were written form.

\section{Funding}

The authors have also declared that no financial support in the research, authorship and publication of this article was received.

\section{Publisher's Note}

Springer Nature remains neutral with regard to jurisdictional claims in published maps and institutional affiliations.

Received: 12 November 2018 Accepted: 14 January 2019

Published online: 24 January 2019

\section{References}

1. Pandey U, Bansal P. What is cervical cancer? J Gynecol Women's Health. 2017. https://doi.org/10.19080/JGWH.2017.02.555599.

2. Ault KA, Future II Study Group. Effect of prophylactic human papillomavirus L1 virus-like-particle vaccine on risk of cervical intraepithelial neoplasia grade 2, grade 3, and adenocarcinoma in situ: a combined analysis of four randomised clinical trials. Lancet. 2007;369:1861-8.

3. WHO. Comprehensive cervical cancer control, a guide to essential practice. In: Uterine cervical neoplasms diagnosis, prevention and control, and therapy. Geneva: WHO.

4. Ntekim A. Cervical cancer in Sub Sahara Africa. London: IINTECH OPEN ACCESS; 2012.

5. Ali Cl, Makata NE, Ezenduka PO. Cervical cancer: a health limiting condition. Gynecol Obstet (Sunnyvale). 2016;6:378.

6. Clark A. The US President's emergency plan for AIDS relief (PEPFAR) cervical cancer prevention and screening regional workshop. June 21, 2010.

7. Asseffa NA. Cervical cancer: Ethiopia's outlook. J Gynecol Womens Health. 2017:5:555660.

8. WHO. World cancer factsheet. World cancer burden. Cancer research UK. 2012

9. G. c. f. sheets. Estimated incidence, mortality and prevalence worldwide. 2012.http://globocan.iarc.fr/old/FactSheets/cancers/cervix-new.asp. Accessed 8 Feb 2018.

10. N. a. C. H. African Coalition on Maternal. Africa cervical cancer multi indicator. Global/Africa Continental/sub regional and country trends; \& links with $\mathrm{SRH}, \mathrm{HIV} / \mathrm{AIDS}$, Adolescent \& Maternal Health.

11. LIVESTRONG, American Cancer Society. The global economic cost of cancer. Atlanta, Georgia: ACS; 2010. http://www.cancer.org/acs/groups/ content/@internationalaffairs/documents/document/acspc-026203.pdf.

12. Gebresilassie FE, Damen MH. Factors influencing people's willingnessto-buy insecticide-treated bednets in Arbaminch Zuria district, southern Ethiopia. J Health Popul Nutr. 2011;29:200-6.

13. Tamiru A, Tsegay G, Wubie M, Gedefaw M. Podoconiosis patients' willingness to pay for treatment services in Northwest Ethiopia: potential for cost recovery. BioMed Central Public Health. 2014;14:259.

14. Prata N, Bell S, Weidert K, Gessessew A. Potential for cost recovery: women's willingness to pay for injectable contraceptives in Tigray, Ethiopia. Public Libr Sci. 2013;8:e64032.

15. Javan N, Zahra K, Ahmad F, Mohammad K. Identification determinant factors on willingness to pay for health services in Iran. Health Econ Rev. 2017:7:40.

16. Umeh IB, Nduka SO, Ekwunife OI. Mothers' willingness to pay for HPV vaccines in Anambra state, Nigeria. Cost Eff Resour Alloc. 2016;14:8.

17. Maharajan MK, Rajiah K, Num KSF, Yong NJ. Knowledge of human papillomavirus infection, cervical cancer and willingness to pay for cervical cancer vaccination. Asian Pacific J Cancer Prev. 2015;16:5733-9.

18. Seiyefa B, Best O, Precious GK. Willingness to pay for clinical preventive services of patients attending the general out-patient clinic of a tertiary hospital in south-south Nigeria. Eur J Prev Med. 2015;3:6-10.

19. Cyril CD, Cajetan CO, Ngozi RD, Judith CC. Cervical cancer screening among HIV-positive women in Nigeria: an assessment of use and willingness to pay in the absence of donor support. J Int Assoc Provid of AIDS Care. 2015;14:241-4.

20. Azimatun AN, Saperi S, Syed AM. Factors influencing willingness to pay for health care. BioMed Central Public Health. 2012;12:A37.

21. Moradi N, Rashidian A, Rasekh HR, Olyaeemanesh A, Foroughi M, Mohammadi T. Monetary value of quality-adjusted life years (QALY) among patients with cardiovascular disease: a willingness to pay study (WTP). Iranian J Pharm Res. 2017;16:823-33.

22. Krupnick A, Alberini A, Cropper M, Simon N, O'Brien B, Goeree R, Heintzelman M. Age, health and the willingness to pay for mortality risk reductions. J Risk Uncertain. 2002;24(2):161-86.

23. Kumlachew A, Alemayehu W, Shimels H, Ayalew A. Association between socioeconomic status and willingness to pay for medical care among government school teachers in Addis Ababa. Sci J Public Health. 2015;3:677-85.

24. Birmeta K, Dibaba Y, Woldeyohannes D. Determinants of maternal health care utilization in Holeta town, central Ethiopia. BMC Health Serv Res. 2013;13:256

25. Johnson FR, Manjunath R, Mansfield CA, Clayton LJ, Hoerger TJ, Zhang P. High-risk individuals' willingness to pay for diabetes risk-reduction programs. Diabetes Care. 2006;29:1351-6.

26. Son KM, Young SN, Hee YJ, Cheol PE, KuiSon C. Women's willingness to pay for cancer screening. J Prev Med Public Health. 2006;39:331-8.

27. Rashmita B. Willingness-to-pay to prevent Alzheimer's disease: a contingent valuation approach. Int J Health Care Finance Econ. 2013;13:233-45. 